\title{
Openness, Government Size and Economic Growth in Nigeria
}

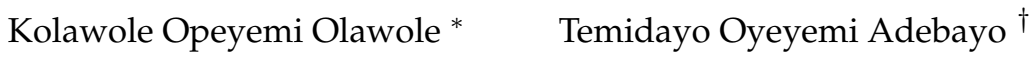 \\ Opeoluwa Samuel Idowu $\ddagger$
}

\begin{abstract}
This study empirically examined the link among openness, government size and economic growth in Nigeria. For our empirical analysis, we utilized the autoregressive distributed lag (ARDL) approach to cointegration. Our analysis reports that in the long run, both financial openness and trade openness had a negative but insignificant impact on economic growth while on the other hand, physical capital and government size had significant positive and negative impacts on economic growth, respectively. Short run results reveal that financial openness, physical capital and government size had significant negative impacts on economic growth while trade openness had a significant positive impact on economic growth. The study concluded that openness and government size do not positively contribute to the country's economic growth performance which implies that efforts by the government at eliminating constraints and impediments to free trade and the movement of capital across borders as well as increases in government size have not yielded the desired economic benefits.
\end{abstract}

Keywords: Financial openness, trade openness, economic growth, government size

\section{Introduction}

In the world today, one of the foremost issues that have dominated discussions and debates on policy making in countries all over the world is the need to eliminate and ease impediments on free trade and the movement of capital. This explains why majority of the reforms and policies adopted in the last three decades have been focused on these issues. In recent times, the vagaries that come with a larger degree of economic openness and the resulting increases in government size have also been receiving attention. In explaining this phenomenon, scholars have put forward arguments postulating that a greater degree of economic openness would result in a greater external risk exposure. A larger public sector will therefore be required to enable government cushion the negative impacts this external risk might have on the economy and the standard of living of the country's citizens.

The major step towards greater economic openness started in Nigeria in 1986 with the adoption of the Structural Adjustment Programme (SAP). This policy introduced several reform measures that were aimed at liberalizing the financial system and reducing government control. Also, a number of reform measures were also targeted at trade liberalization. Before 1986, import substitution was the major policy on which the country's

\footnotetext{
*Department of Economics, Obafemi Awolowo University, Ile-Ife, Nigeria. Email: kholarr_ola@yahoo.com

${ }^{\dagger}$ Department of Economics, Obafemi Awolowo University, Ile-Ife, Nigeria.

${ }^{\ddagger}$ Department of Economics, Obafemi Awolowo University, Ile-Ife, Nigeria.
} 
trade policy was premised. However, beginning from 1986, attention was shifted to export promotion. This policy transition in the area of trade explains why trade is one of the most important engines of economic growth in Nigeria. Between 1986 and 1987, trade to GDP ratio increased from $23.7 \%$ to $41.6 \%$ and further to $53 \%$ in 1990 . It rose to $59.7 \%$ in 1995 and by 1999, it had risen to $59.8 \%$. Trade to GDP ratio also averaged $52.8 \%$ between the period, 2000 and 2015 (World Bank, 2015). While foreign direct investment (FDI) inflows increased from $1.3 \%$ of GDP (pre-liberalization) to an average of $2.6 \%$ of GDP after the adoption of the SAP policy (World Bank, 2015).

In the last three decades, the size of the public sector has also increased tremendously. On average, the size of government was 8.7\% of GDP between the periods, 1986 and 2015 reaching a maximum of $17.9 \%$ in 1994 and a minimum of $4.8 \%$ in 1994 (World Bank, 2015). However, despite significant improvements in these economic variables, the expected economic growth benefits are yet to materialize. The growth rate of Nigeria in 1986 was $3 \%$ when the liberalization policy commenced but declined to $-1 \%$ in 1987 . It thereafter increased to $10 \%$ in 1988 and declined to 7\% in 1989. From 1990 to 1994, there was a continuous decline reaching as low as 1.3\% in 1994. Between 1995 and 1996, there was little improvement with the economy growing from $2 \%$ to $4 \%$. It further declined from 3\% in 1997 to $1 \%$ in 1999 . Owing to some policy measures, the economy improved to $5 \%$ in 2000 but declined further to $3 \%$ and $2 \%$ in 2001 and 2002 respectively (World Bank, 2015; CBN, 2015). Between 2003 and 2004, growth rate, averaged 10.5\% while between 2005 and 2015; GDP growth averaged 5.82 percent (World Bank, 2015; CBN, 2015). In the first quarter of 2016, the Nigerian economy contracted by $0.36 \%$ and further by $2.06 \%$ in the second quarter. This led to the country being officially declared to be in recession having posted two consecutive quarters of declining growth.

On the empirical side, the relationship among openness (financial and trade openness), government size and economic growth is well documented in the empirical literature, however, most studies merely introduced trade openness as an explanatory variable. The empirical studies by Zaidi, Karim, and Kefeli (2005); Mallick (2008); Zakaria and Ahmed (2013); Alshahrani and Alsadiq (2014) found that trade openness and government size both impacted economic growth positively while Zareen and Qayyum (2015) finds that the impact of financial and trade openness is positive and negative for government size. A major drawback of these studies is that they only took into account, one measure of openness, trade openness. This is not fully justified on empirical grounds, given the fact that over time, financial openness, has increased in quantitative importance.

In Nigeria, a good number of the available studies have either focused on the relationship between trade openness and economic growth (Saibu, 2012; Kalu, 2015; Osabuohien, 2007) or financial openness and economic growth (Saibu, 2012; Orji, 2014). The empirical study by Feridun, Olusi, and Folorunso (2006) also investigated the relationship among trade openness, financial integration and economic growth. In the empirical contribution by Nduka (2013), the relationship among trade openness, government size and economic growth was investigated. However, this study failed to account for financial openness. Given the fact that majority of reform measures have been mostly targeted at financial liberalization, accounting for financial openness becomes empirically expedient. In the light of all these, it is important to revisit the link among openness, government size and 
economic growth in Nigeria.

\section{Literature Review}

In the last few decades, the link among openness, government size and economic growth has attracted the attention of a number of researchers. The empirical study by Zareen and Qayyum (2015), using the VAR technique examined the impact of government size and other determinants on economic growth over the period 1973-2012. From the reported results, it is observed that a large government impedes economic growth performance while capital openness and trade openness impacted economic growth positively. In a related study by Alshahrani and Alsadiq (2014), the impact of various forms of government expenditures was examined in Saudi Arabia over the period 1969-2010. From the empirical findings, it is reported that in the long run, public and private investments as well as healthcare expenditure, stimulates economic growth while trade and housing sector expenditure only improves economic growth in the short-run. A related study on eight selected MENA countries by Sabra (2016) also provided empirical evidence on the connection among government size, country size, openness and economic growth. Based on the reported results, it is concluded that when government size is above its threshold value, the relationship between government size and economic growth becomes negative. In the empirical contribution by Mollick and Cabral (2015), it is reported that the impact of government size is negative while openness has a positive effect while the study by Olasode, Raji, Adedoyin, and Ademola (2015) reports that trade openness and government expenditure explain the long run movements of economic growth.

Overall, empirical studies on the link among openness, government size and economic growth are generally few. Most of the extant literature is majorly focused on the nexus between openness (financial openness and trade openness) and economic growth or government size and economic growth. In the empirical contribution by Kose, Prasad, and Terrones (2009), what globalization portends for economic growth was examined based on a dataset that comprises 145 countries. The study finds that the impact of financial globalization depends on the measures of financial integration employed. In specific terms, the study notes there is a higher tendency that empirical works based on de facto integration would find a positive impact.

A similar study by Özdemir and Erbil (2008) also investigated what financial liberalization portends for economic growth in Turkey and 10 new EU member countries. Results showed that economic growth is negatively related to de jure measure of financial openness and positively related to de facto measures of financial openness in Turkey. For the $10 \mathrm{EU}$ countries, results revealed that de facto measures of financial openness impacted economic growth positively. In the empirical study by Edwards (2000) based on a sample of twenty emerging and industrial economies, empirical evidence revealed that countries that are more open to financial transactions perform better. However, it is shown that the positive impact of financial openness only manifests when the nation has achieved a certain level of economic development. In the study by Arteta, Eichengreen, and Wyplosz (2001), the positive impact of financial openness manifests only in countries 
with strong institutions. Empirical evidence supporting the assertion that capital account liberalization improves as a country's financial systems deepens were rather fragile. This result supports those reported in the studies by Shahbaz, Wahid, Ahmad, and Chaudhary (2008); Kim, Lin, and Suen (2012). Orji (2014) also investigated the link between financial openness and growth in Nigeria. Results reported that financial openness impacts economic growth positively both in the long run and short run.

In the literature, the trade openness-economic growth nexus has also been documented by a number of studies, but so far, empirical results have been mostly mixed and inconclusive. The empirical contributions by Dollar (1992); Edwards (1998); Frankel and Romer (1999); Edwards (1993) finds that trade openness have a positive impact on growth. However, most of these studies have been criticized for not accounting for major control variables, the endogeneity of trade to GDP growth and adoption of limited data samples and inappropriate estimation techniques. In the contribution by Andersen and Babula (2009), the most cited empirical studies in this area were reviewed. In their submission, they postulate that a positive relationship between trade and growth was plausible. The study by Nduka (2013) also examined whether trade openness stimulates economic growth in Nigeria. From the empirical results, it is concluded that trade openness improves economic growth. The survey of the literature reveals that the extant literature is replete with studies that only accounted for one dimension of openness, namely, trade openness. As we stated earlier, accounting for only trade openness only reveals information about a single dimension of openness. Given the fact that most reform measures has been targeted at opening up the Nigerian economy to foreign capital flows, accounting for financial openness becomes highly expedient.

\section{Data and Methodology}

\section{Theoretical Framework}

In this study, our theoretical framework rests on the simple endogenous growth theory with government spending. As a starting point, we specify a model based on the assumption of a representative infinite-lived household in a closed economy that seeks to maximize overall utility. This is expressed as

$$
U=\int_{0}^{\infty} u(c) e^{-\rho t} d t
$$

where $c$ is consumption per person and $\rho>0$ is the constant rate of time preference. Population, which corresponds to the numbers of workers and consumers is constant. Using an intertemporal utility function with a constant elasticity of substitution $(\sigma)$ :

$$
u(c)=\frac{c^{1-\sigma}-1}{1-\sigma}
$$


Substituting equation 2 into equation 1, we have:

$$
U=\int_{0}^{\infty} \frac{c^{1-\sigma}-1}{1-\sigma} e^{-\rho t} d t
$$

where $\sigma>0$, so that marginal utility has the constant elasticity $-\sigma$.

We further represent the production function of each household as follows:

$$
y=f(k)
$$

where $y$ is output per worker and $k$ is capital per worker. Assuming constant returns to a broad concept of capital following Rebelo (1991), we have:

$$
y=A k
$$

where $A>0$ is the constant net marginal product of capital (constant).

We modify this model to account for the public sector following (Barro, 1990). According to Barro (1990), the private sector considers public sector services as a productive input. If denotes the amount of public sector services provided to each producer-household, then, we can restate equation 5 as follows:

$$
y=A k^{\alpha} g^{\beta}
$$

where $\beta=1-\alpha$ and $\alpha+\beta=1, y=$ output per worker, $A=$ Total factor productivity or level of technology, $k=$ capital per worker, $g=$ per capita government purchases.

Linearizing equation (6),

$$
\ln y=\ln A_{0}+\alpha \ln k+\beta \ln g
$$

The empirical literature is replete with studies that employed Barro's simple model of endogenous growth to investigate the nexus between government size and economic growth (Guseh, 1997; Bergh \& Henrekson, 2011; Afonso \& Jalles, 2011). In order to account for openness (financial openness and trade openness), this study will make some necessary augmentations following a number of studies. In this study, the necessary augmentations is carried out following (Amir \& Dar, 2002; Anaman, 2004; Zareen \& Qayyum, 2015) in that they assume that the impact of other variables on economic growth comes through their impact on total factor productivity. Taking a cue from these studies, we assume that financial openness and trade openness affects the quantity of physical capital and economic growth through total factor productivity. In addition, increasing degree of openness is expected to lead to a rise in government size. Thus, it is assumed that total factor productivity is determined by financial openness and trade openness. More specifically, $A_{0}$ can be expressed as:

$$
A_{0}=\alpha_{0}+\alpha_{1} F O+\alpha_{2} T O
$$


where $F O=$ financial openness and $T O=$ trade openness. Substituting equation (8) into equation (7), we get the following version of our extended Barro model:

$$
A_{0}=\alpha_{0}+\alpha_{1} F O+\alpha_{2} T O+\alpha_{3} k+\alpha_{4} g
$$

Equation (9) describes the evolution of output per worker, as a function of financial openness, trade openness, the level of physical capital and government size.

\section{Data and Empirical Modeling}

This study employs annual data covering the period, 1986 to 2015. Data on government size, trade openness, economic growth and physical capital were sourced from the World Development Indicators (WDI) while data on financial openness was sourced from the Lane and Milesi-Feretti dataset. In line with the theoretical framework above, the model specification for this study is stated as follows:

$$
Y_{t}=f\left(F O_{t}, T O_{t}, K_{t}, G S_{t}\right)
$$

The model relating the link among openness, government size and economic growth is specified in econometric form as:

$$
Y_{t}=\beta_{0}+\beta_{1} F O_{t}+\beta_{2} T O_{t}+\beta_{3} K_{t}+\beta_{4} G S_{t}+\epsilon_{t}
$$

where $\mathrm{Y}$ is economic growth, FO measures financial openness, $\mathrm{TO}$ is trade openness, $\mathrm{K}$ is physical capital, GS is government size, $\epsilon$ is the error term and $t$ is time period. Financial openness, trade openness and government size are measured as a percentage of GDP (\% of GDP) while physical capital and economic growth are measured in US\$ dollars.

\section{Unit Root Test}

One of the first key steps in time series analysis is checking for the stationary properties of variables. In this study, we employ the Augmented Dickey-Fuller (ADF) and PhillipsPerron approaches. The Augmented Dickey Fuller approach is robust even in the presence of serial correlation while the Phillips-Perron test corrects for serial correlation by means of non-parametric statistical methods.

\section{The ARDL Bounds Testing}

This study employed the Auto Regressive Distributed Lag (ARDL) model of Pesaran, Shin, and Smith (2001) to analyze the effect of openness and government size on economic growth in Nigeria. The model is stated as follows: 


$$
\begin{aligned}
& \Delta \ln Y_{t}=\alpha_{0}+\sum_{j=1}^{p} \vartheta_{j} \Delta \ln Y_{t-j}+\sum_{j=0}^{a} \delta_{j} \Delta F O_{t-j}+\sum_{j=0}^{m} \phi_{j} \Delta T O_{t-j}+\sum_{j=0}^{a} \gamma_{j} \Delta \ln K_{t-j} \\
& +\sum_{j=0}^{b} \theta_{j} \Delta G S_{t-j}+\beta_{1} \ln Y_{t-1}+\beta_{2} F O_{t-1}+\beta_{3} T O_{t-1}+\beta_{4} \ln K_{t-1}+\beta_{5} G S_{t-1}+\mu_{t}
\end{aligned}
$$

By reparameterizing, we arrive at the model specified below:

$$
\begin{aligned}
\Delta l n Y_{t}=\alpha_{0}+\sum_{j=1}^{p} \vartheta_{j} \Delta \ln Y_{t-j}+\sum_{j=0}^{a} \delta \Delta F O_{t-j} & +\sum_{j=0}^{b} \phi_{j} \Delta T O_{t-j}+\sum_{j=0}^{c} \gamma_{j} \Delta \ln K_{t-j} \\
& +\sum_{j=0}^{d} \theta_{j} \Delta G S_{t-j}+\psi E C M_{t-1}+\mu_{t}
\end{aligned}
$$

$\Delta$ signify the first difference operator, $\alpha_{0}$ is the drift component, $p$ is the lag length and $\mu_{t}$ is the error term. $\left(\vartheta_{j} \delta_{j} \phi_{j} \gamma_{j} \theta_{j} \sigma_{j}\right)$ indicates the short run effects.

\section{Empirical Results}

Table 1 present the descriptive statistics. From the result, it is observed that a higher level of consistency is displayed by the variables in that the median and mean values have values that lie between the maximum and minimum values. We also report that the standard deviation is low for most of the variables. In Table 2, we present the unit root tests using the Augmented Dickey Fuller (ADF) and Phillips Perron (PP) approaches. From the results, it is evident that we have a combination of $\mathrm{I}(0)$ and $\mathrm{I}(1)$ variables. In specific terms, government size is stationary at level while the other variables became stationary at first difference. Since we have a combination of $\mathrm{I}(0)$ and $\mathrm{I}(1)$ variables, the most appropriate econometric tool is the Autoregressive Distributed Lag (ARDL) estimation technique. The ARDL technique requires the selection of optimal and appropriate lags. In this study, we adopt the AIC criterion due to its small sample properties. Acquah (2010) notes that this criterion performs better when we are dealing with small samples, it is however inconsistent when the sample is large. Table 3 presents the result of the lag selection criteria.

In Table 4, we present the bound test result. The result shows that the F-Statistic (4.75) is greater than the upper bound value (4.01) at the $5 \%$ significance level. This suggests the existence of long run cointegrating relationships. From this, we can deduce and conclude that openness, government size and economic growth are tied together in the long run. In Table 5, we present results of the long run and short run empirical analysis. In the long run, the impact of financial openness on economic growth is negative but insignificant. The empirical findings by Feridun et al. (2006); Olasode et al. (2015) conform with the result obtained. Those reported by Orji (2014); Owusu and Odhiambo (2014) are however not in agreement. This result can be explained by a number of factors. In recent times, 
capital flows and the degree of financial openness have been declining and for a country like Nigeria that is heavily reliant on the inflow of foreign capital, a sudden disruption in capital flows will result in severe financing difficulties.

Next, we report the impact of trade openness. For this variable, we report a negative but insignificant impact. This result conforms with previous studies by Jawaid (2014); Eric (2015); Kalu (2015). The negative effect of trade openness on economic growth can be ascribed to the fall in the international price of crude oil which accounts for majority of the country's exports. This has resulted in declining foreign exchange earnings, exchange rate volatility, rising inflation and a huge drop in government revenue. The level of physical capital $(\mathrm{K})$ also reported a positive and significant impact. We expect that a percent change in physical capital will increase economic growth by $1.28 \%$. This result is in line with the theoretical expectation. Thus, the accumulation of capital is needed to achieve sustained increases in economic growth. The reported empirical findings conform with those reported by Zareen and Qayyum (2015).

On the contrary, the impact of government size on economic is negative and significant. We expect that a percent change in the size of government will result in a $0.08 \%$ reduction in economic growth. A simple explanation for the negative impact recorded is the fact that majority of government spending goes to recurrent expenditure, while capital expenditure that could help stimulate growth receives a small share. The Nigerian economy is also characterized by the twin problems of mismanagement and corruption, consequently, government funds that should have gone into implementing and executing projects ends up in private hands. Also, the reported result conforms to the findings by Ahmed (2012); Afonso and Jalles (2011); Zareen and Qayyum (2015). Table 6 presents the short run results. We report that financial openness (at lag 1) exerts a negative and significant impact on economic growth. To put it simply, we expect that for a one percent change in the level of financial openness (at lag 1), economic growth will record a $0.008 \%$ decline. The empirical findings by Kim et al. (2012) supports this result while it is contrary to findings by Evans (2013); Orji (2014). Trade openness (current year value) was reported to exert a significant positive impact on economic growth. It is expected that economic growth will increase by $0.008 \%$ for a percent change in trade openness. This finding supports the results by Hye and Lau (2014); Sikwila, Ruvimbo, and Mosikari (2014); Ali and Abdullah (2015).

The level of physical capital (current year value) also reported a significant negative impact while the previous year value (at lag 1 ) had a positive and significant effect. A percent change in the current year value of the level of physical capital will therefore reduce economic growth by $1.22 \%$ while a percent change in the previous year value (lag of 1) of the level of physical capital will increase economic growth by $1.40 \%$. In addition, a percent change in government size (at lag 1) exerted a negative and significant impact on economic growth. At lag 1, a percent change in government size reduced economic growth by $0.08 \%$ while at lag 2 , a percent change in government size increased economic growth by $0.06 \%$. This is in line with the findings by Ahmed (2012); Zareen and Qayyum (2015); Kolawole (2016). We also find that the previous period value of economic growth impacts economic growth negatively in the current period.

The ECM value (-0.8345) reveals that approximately $83 \%$ of disequilibrium errors are 
corrected in one year. Also, the R2 and Adjusted R2 reports that the explanatory variables explains $99 \%$ and $97 \%$ of the total variation in the dependent variable respectively. While the Durbin-Watson (1.74) reveals that our model does not suffer from serial correlation. Table 7 presents the result of the diagnostic tests (heteroscedasticity, serial correlation LM test, test for normality, functional form). Two stability tests, cumulative sum (CUSUM) and cumulative sum of squares (CUSUMsq) of the residuals was also carried out. Our diagnostic tests results reveal that our model satisfies the requirements of these tests. Results of the stability tests (CUSUM and CUSUMsq) also reveal that the parameters of the model are stable as the graph depicted in Figure 1 lies within the critical bounds (at 5\%).

\section{Conclusion}

This study empirically examined the link among openness, government size and economic growth in Nigeria and based on the empirical results obtained, a number of conclusions are drawn. The empirical estimates from this study revealed that financial openness, trade openness and government size impacts economic growth negatively in the long run while on the other hand, the impact of physical capital is positive and significant. These reported results are also in consonance with the short run results with the exception of physical capital whose current and previous year value impacted economic growth positively and negatively respectively. Thus, from the reported results, it is quite evident that the efforts by the government at removing restrictions to cross-border financial transactions (financial openness) and trade have not yielded the expected benefits. Also, marginal increases in government size have not translated into a better economic growth performance. Thus, there is need for the government to carry out far reaching reforms as well as strengthen the nations institutions. These will go a long way in ensuring that the growth inducing benefits of greater openness and a rising government size materializes. Further studies should explore the differential impact of the various categories of government spending. This will broaden our knowledge and enrich the extant literature on the subject matter.

Figure 1

Cusum and Cusum of Squares Stability Tests

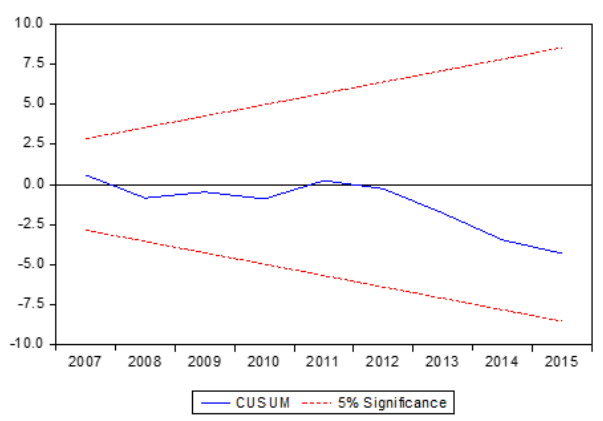

(a) Cusum

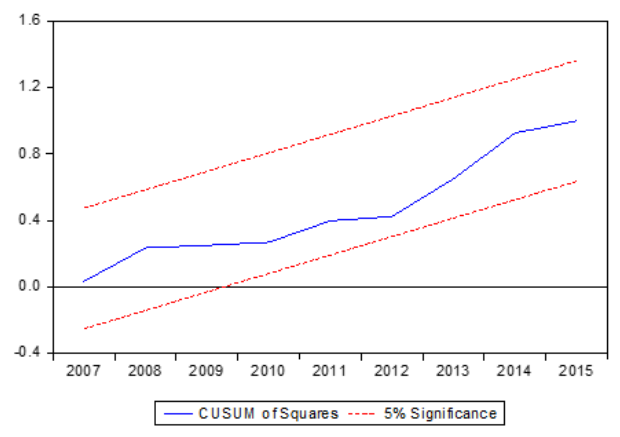

(b) Cusum of Squares 
Table 1

Descriptive Statistics of the Variable

\begin{tabular}{lccccc}
\hline Statistic/Variable & $\mathbf{Y}$ & FO & TO & K & GS \\
\hline Mean & 928.7902 & 78.87112 & 54.22697 & $1.92 \mathrm{E}+10$ & 8.616293 \\
Median & 363.8802 & 55.50473 & 57.90042 & $3.96 \mathrm{E}+09$ & 7.425769 \\
Maximum & 3203.244 & 172.3755 & 81.81285 & $8.98 \mathrm{E}+10$ & 17.94384 \\
Minimum & 153.0757 & 31.51432 & 21.44693 & $2.02 \mathrm{E}+09$ & 4.833249 \\
Std. Dev. & 976.1019 & 45.38459 & 15.42919 & $2.82 \mathrm{E}+10$ & 3.141211 \\
Skewness & 1.25869 & 0.660129 & -0.44625 & 1.483921 & 1.145341 \\
Kurtosis & 3.023682 & 2.040919 & 2.52726 & 3.464346 & 3.808796 \\
Jarque-Bera & 7.922203 & 3.328648 & 1.275047 & 11.27962 & 7.37672 \\
Sum & & & & & \\
Sum Sq. Dev. & 27863.71 & 2366.134 & 1626.809 & $5.76 \mathrm{E}+11$ & 258.4888 \\
Observations & 27630474 & 59733.07 & 6903.735 & $2.31 \mathrm{E}+22$ & 286.149 \\
\hline Source: Resercher & & & & & \\
\hline
\end{tabular}

Source: Researcher's Computation

Note: Y, FO, TO, PCA and GS denotes economic growth (US\$), financial openness ( $\%$ of GDP), trade openness (\% of GDP), physical capital (US\$) and government size (\% of GDP), respectively.

Table 2

Result of Unit Root Tests

\begin{tabular}{|c|c|c|c|c|c|c|}
\hline \multirow[b]{2}{*}{ Variables } & \multirow[b]{2}{*}{ Level } & \multicolumn{2}{|l|}{ ADF } & \multicolumn{2}{|r|}{ PP } & \multirow[b]{2}{*}{ Status } \\
\hline & & First Diff. & Status & Level & First Diff. & \\
\hline $\ln Y$ & $\begin{array}{c}0.001 \\
{[0.9512]}\end{array}$ & $\begin{array}{c}-5.6828 \\
{[0.0001]^{* * *}}\end{array}$ & $\mathrm{I}(1)$ & $\begin{array}{c}0.1856 \\
{[0.9668]}\end{array}$ & $\begin{array}{c}-5.7151 \\
{[0.0001]^{* * *}}\end{array}$ & $\mathrm{I}(1)$ \\
\hline $\mathrm{FO}$ & $\begin{array}{c}-1.6008 \\
{[0.4694]}\end{array}$ & $\begin{array}{l}-5.941737 \\
{[0.0000]^{* * *}}\end{array}$ & $\mathrm{I}(1)$ & $\begin{array}{c}-1.5253 \\
{[0.5069]}\end{array}$ & $\begin{array}{c}-5.9116 \\
{[0.0000]^{* * *}}\end{array}$ & $\mathrm{I}(1)$ \\
\hline $\mathrm{TO}$ & $\begin{array}{c}-2.5947 \\
{[0.1055]}\end{array}$ & $\begin{array}{c}-3.851 \\
{[0.0087]^{* * *}}\end{array}$ & $\mathrm{I}(1)$ & $\begin{array}{c}-2.5791 \\
{[0.1087]}\end{array}$ & $\begin{array}{c}-8.0155 \\
{[0.0000]^{* * *}}\end{array}$ & $\mathrm{I}(1)$ \\
\hline $\ln K$ & $\begin{array}{c}-2.1624 \\
{[0.2238]}\end{array}$ & $\begin{array}{c}-9.0026 \\
{[0.0000]^{* * *}}\end{array}$ & $\mathrm{I}(1)$ & $\begin{array}{c}-4.8639 \\
{[0.0005]^{* * *}}\end{array}$ & & $\mathrm{I}(0)$ \\
\hline GS & $\begin{array}{c}-3.3455 \\
{[0.0218]^{* *}}\end{array}$ & & $\mathrm{I}(0)$ & $\begin{array}{c}-3.4016 \\
{[0.0192]^{* *}}\end{array}$ & & $\mathrm{I}(0)$ \\
\hline
\end{tabular}

Source: Researcher's Computation

Note: ${ }^{* * *}$ indicates significance at $1 \%$ level and ${ }^{* *}$ indicates significance at $5 \%$. ADF is Augmented Dickey- Fuller test and PP is Phillips-Perron test.

Table 3

Lag Length Selection Criteria

\begin{tabular}{lcccccc}
\hline Lag & LogL & LR & FPE & AIC & SC & HQ \\
\hline 0 & -393.4948 & NA & 4542169 & 29.51813 & 29.7581 & 29.58949 \\
1 & -322.8562 & 109.8822 & 160462.3 & 26.1375 & $27.57731^{*}$ & 26.56563 \\
2 & -285.7456 & $43.98296^{*}$ & $80978.61^{*}$ & 25.24041 & 27.88008 & $26.02532^{*}$ \\
3 & -258.2892 & 22.37185 & 127985.6 & $25.05846^{*}$ & 28.89798 & 26.20015 \\
\hline
\end{tabular}

Source: Researcher's Computation

Note: * indicates lag order selected by the criterion; LR, FPE, AIC, SIC and HQ indicate sequential modified LR test statistic, Final Prediction Error, Akaike Information Criterion, Schwarz Information Criterion and Hannan-Quinn, respectively. 
Table 4

ARDL Bounds Test

\begin{tabular}{lcccc}
\hline F-Statistic & No of Regressors & Critical Values & I(0) & I(1) \\
\hline 4.746846 & 4 & $10 \%$ & 2.45 & 3.52 \\
& & $5 \%$ & 2.86 & 4.01 \\
& & $1 \%$ & 3.74 & 5.06 \\
\hline
\end{tabular}

Source: Researcher's Computation

Table 5

Long Run Regression Result

\begin{tabular}{lcccc}
\cline { 1 - 2 } Dependent Variable $(\ln Y)$ & & & & \\
\cline { 1 - 4 } Variable & Coefficient & Std. Error & t-Statistic & Prob. \\
\hline FO & -0.004973 & 0.002666 & -1.86504 & $0.0950^{*}$ \\
TO & -0.012398 & 0.006332 & -1.958059 & $0.0819^{*}$ \\
lnK & 1.278762 & 0.183374 & 6.973506 & $0.0001^{* * *}$ \\
GS & -0.081125 & 0.032773 & -2.475384 & $0.0353^{* *}$ \\
\hline
\end{tabular}

Source: Researcher's Computation

Note: ${ }^{* * *}$ indicates significance at $1 \%$ level, ${ }^{* *}$ indicates significance at $5 \%$.

* indicates significance at $10 \%$.

Table 6

Short Run Parsimonious Regression Result

\begin{tabular}{|c|c|c|c|c|}
\hline Dependent Variable $(\ln Y)$ & & & & \\
\hline Variable & Coefficient & Std. Error & t-Statistic & Prob. \\
\hline $\mathrm{D}(\ln \mathrm{Y}(-1))$ & -0.879796 & 0.35457 & -2.48131 & $0.0349 * *$ \\
\hline $\mathrm{D}(\ln Y(-2))$ & 0.798711 & 0.29558 & 2.702179 & $0.0243^{* *}$ \\
\hline $\mathrm{D}(\mathrm{FO})$ & -0.008137 & 0.002045 & -3.97901 & $0.0032^{* * *}$ \\
\hline $\mathrm{D}(\mathrm{TO})$ & 0.007784 & 0.007049 & 1.104245 & $0.0175^{* *}$ \\
\hline $\mathrm{D}(\ln K)$ & -1.22253 & 0.460153 & -2.65679 & $0.0262^{* *}$ \\
\hline $\mathrm{D}(\ln K(-1))$ & 1.398234 & 0.395015 & 3.539697 & $0.0063^{* *}$ \\
\hline $\mathrm{D}(\mathrm{GS}(-1))$ & -0.083178 & 0.023646 & -3.51757 & $0.0065^{* *}$ \\
\hline $\mathrm{D}(\mathrm{GS}(-2))$ & 0.064901 & 0.024971 & 2.598999 & $0.0288^{* *}$ \\
\hline $\operatorname{ECM}(-1)$ & -0.834542 & 0.28883 & 2.889388 & $0.0179 * *$ \\
\hline$R^{2}$ & 0.989883 & & & \\
\hline Adjusted $R^{2}$ & 0.970774 & & & \\
\hline D-W Test & 1.73567 & & & \\
\hline F-statistic & $51.80134(0.000001)$ & & & \\
\hline
\end{tabular}

Table 7

ARDL Model Diagnostic Test

\begin{tabular}{lcc}
\hline Test Statistic & F-Statistics & P-Value \\
\hline Serial Correlation & 1.9819 & 0.208 \\
Functional Form & 0.8965 & 0.3961 \\
Normality & $0.8453^{*}$ & 0.6553 \\
Heteroscedasticity & 0.6797 & 0.7645 \\
\hline \multicolumn{2}{l}{ Source: Researcher's Computation } \\
Note: * denotes JB statistic and not F-statistic
\end{tabular}




\section{References}

Acquah, H. D. (2010). Comparison of Akaike information criterion (AIC) and Bayesian information criterion (BIC) in selection of an asymmetric price relationship. Journal of Development and Agricultural Economics, 2(1), 1-6.

Afonso, A., \& Jalles, J. (2011). Economic performance and government size. European Central Bank Working Paper Series No. 1399.

Ahmed, M. (2012). Openness, institutions, and economic growth: Empirical evidence from panel estimation.

Ali, W., \& Abdullah, A. (2015). The impact of trade openness on the economic growth of Pakistan: 1980-2010. Global Business \& Management Research, 7(2), 120-129.

Alshahrani, S. A., \& Alsadiq, M. A. J. (2014). Economic growth and government spending in Saudi Arabia: An empirical investigation. IMF Working Paper 2014WP/14/3.

Amir, S., \& Dar, A. A. (2002). Government size, factor accumulation, and economic growth: Evidence from OECD countries. Journal of Policy Modeling, 24(7-8), 679692.

Anaman, K. A. (2004). Determinants of economic growth in Brunei Darussalam. Journal of Asian Economics, 15(4), 777-796.

Andersen, L., \& Babula, R. (2009). The link between openness and long-run economic growth. Journal of International Commerce and Economics, 2, 31-37.

Arteta, C., Eichengreen, B., \& Wyplosz, C. (2001). When does capital account liberalization help more than it hurts? (Tech. Rep.). NBER Working Paper No. 8414.

Barro, R. J. (1990). Government spending in a simple model of endogeneous growth. Journal of Political Economy, 98(5), 103-125.

Bergh, A., \& Henrekson, M. (2011). Government size and growth: A survey and interpretation of the evidence. Journal of Economic Surveys, 25(5), 872-897.

CBN. (2015). Statistical Bulletin. Central Bank of Nigeria, Volume 26, December, 2015.

Dollar, D. (1992). Outward-oriented developing economies really do grow more rapidly: Evidence from 95 LDCs, 1976-1985. Economic Development and Cultural Change, 40(3), 523-544.

Edwards, S. (1993). Openness, trade liberalization, and growth in developing countries. Journal of Economic Literature, 31(3), 1358-1393.

Edwards, S. (1998). Openness, productivity and growth: What do we really know? The Economic Journal, 108(447), 383-398.

Edwards, S. (2000). Capital mobility and economic performance: Are emerging economies different? NBER Working Paper 8076, Cambridge, MA.

Eric, O. O. (2015). Trade liberalization and economic growth in Nigeria: Do concern matters? International Journal of Economics and Empirical Research (IJEER), 3(6), 306311.

Evans, O. (2013). International financial integration and the Nigerian economic performance: A var modeling approach.

Feridun, M., Olusi, J. O., \& Folorunso, B. A. (2006). Analyzing the impact of globalization on economic development in developing economies: An application of error correc- 
tion modelling (ECM) to Nigeria. Applied Econometrics and International Development, $6(3), 173-182$.

Frankel, J. A., \& Romer, D. (1999). Does trade cause growth? American Economic Review, 89(3), 379-399.

Guseh, J. S. (1997). Government size and economic growth in developing countries: A political-economy framework. Journal of Macroeconomics, 19(1), 175-192.

Hye, Q. A., \& Lau, W. (2014). Trade openness and economic growth: Evidence from India. Journal of Business Economics and Management, 16(1).

Jawaid, S. T. (2014). Trade openness and economic growth: A lesson from Pakistan. Foreign Trade Review, 49(2), 193-212.

Kalu, U. D. (2015). Does trade openness make sense? Investigation of Nigeria trade policy. International Journal of Academic Research in Economics and Management Sciences, 4(1), 11-24.

Kim, D.-H., Lin, S.-C., \& Suen, Y.-B. (2012). Dynamic effects of financial openness on economic growth and macroeconomic uncertainty. Emerging Markets Finance and Trade, 48(1), 25-54.

Kolawole, B. O. (2016). Government spending and inclusive-growth relationship in Nigeria: An empirical investigation. Zagreb International Review of Economics and Business, 19(2), 33-56.

Kose, M. A., Prasad, E., \& Terrones, M. (2009). Does openness to international financial flows raise productivity growth? Journal of International Money and Finance, 28(4), 554-580.

Mallick, H. (2008). Government spending, trade openness and economic growth in India: A time series analysis. Working Paper.

Mollick, A. V., \& Cabral, R. (2015). Government size, openness, and output growth: Industrial and developing economies under globalization. University of Texas - Pan American.

Nduka, E. K. (2013). Openness and economic growth in Nigeria. Journal of Education and Practice, 4(1), 68-73.

Olasode, O. S., Raji, O. A., Adedoyin, A. O., \& Ademola, I. S. (2015). Trade openness and economic growth. International Journal of Economics, Commerce and Management, 3(5), 180-202.

Orji, A. (2014). Analysis of financial openness and macroeconomic performance in Nigeria (Unpublished doctoral dissertation).

Osabuohien, E. S. (2007). Trade openness and economic performance of ECOWAS members-reflections from Ghana and Nigeria. African Journal of Business and Economic Research, 2(2-3), 57-73.

Owusu, E. L., \& Odhiambo, N. M. (2014). Financial liberalisation and economic growth in Nigeria: An ARDL-bounds testing approach. Journal of Economic Policy Reform, 17(2), 164-177.

Özdemir, D., \& Erbil, C. (2008). Does financial liberalization trigger long-run economic growth? Evidence from Turkey and other recent EU members, paper prepared for the EcoMod International Conference on Policy Modelling, July 2-4, Berlin. 
Pesaran, M. H., Shin, Y., \& Smith, R. J. (2001). Bounds testing approaches to the analysis of level relationships. Journal of Applied Econometrics, 16(3), 289-326.

Rebelo, S. (1991). Long-run policy analysis and long-run growth. Journal of Political Economy, 99(3), 500-521.

Sabra, M. M. (2016). Government size, country size, openness and economic growth in selected MENA countries. International Journal of Business and Economic Sciences Applied Research, 9(1), 39-45.

Saibu, F. M. (2012). Capital flows, trade openness and economic growth dynamics: New empirical evidence from Nigerian economy. Post-doctoral research, University of Johannesburg, South Africa.

Shahbaz, M., Wahid, A., Ahmad, K., \& Chaudhary, A. (2008). Capital account openness and economic growth nexus: The case study of Pakistan. East-West Journal of Economics and Business, 11(1/2), 11-33.

Sikwila, M. N., Ruvimbo, N. G., \& Mosikari, T. J. (2014). Trade openness and GDP growth nexus in South Africa. Global Journal of Management and Business Research, 14(7), 1-6.

World Bank. (2015). World bank development indicators.

Zaidi, M. S., Karim, Z. A., \& Kefeli, Z. (2005). Financial sector development, government size, trade openness and economic growth: An emperical analysis in ASEAN4 countries. Economic Journal of Emerging Markets, 10(2), 107-121.

Zakaria, M., \& Ahmed, E. (2013). Openness-growth nexus in Pakistan: A macroeconometric analysis. Argumenta Oeconomica, 1(30), 47-84.

Zareen, S., \& Qayyum, A. (2015). An analysis of the impact of government size on economic growth of Pakistan: An endogenous growth. Retrieved from http:// mpra.ub.uni-muenchen. de/56139/MPRAPaperNo.56139. 